\title{
Rapid Construction of a Linkage Map using High-efficiency Genome Scanning/ AFLP and RAPD, Based on an Intraspecific, Doubled-haploid Population of Capsicum annuum
}

\author{
Toru Sugita*1), Tetsuji Kinoshita ${ }^{1)}$, Tomoe Kawano'), Kenichi Yuji ${ }^{1,5)}$, Kazunori Yamaguchii ${ }^{1,6)}$, \\ Ryutaro Nagata ${ }^{1,7)}$, Akifumi Shimizu ${ }^{2)}$, Lanzhuang Chen ${ }^{3)}$, Shinji Kawasaki ${ }^{4)}$ and Atsushi Todoroki ${ }^{1)}$ \\ 1) Miyazaki Prefectural Agricultural Experiment Station, 5851 Minemae, Shimonaka, Sadowara, Miyazaki 880-0212, Japan \\ 2) Nihon University, Kameino, Fujisawa, Kanagawa 252-8510, Japan \\ 3) Miyazaki University, Kibana, Miyazaki, Miyazaki 889-2192, Japan \\ 4) National Institute of Agrobiological Siences, 2-1-2 Kannondai, Tsukuba, Ibaraki 305-8602, Japan \\ 5) Present address: Koyu Agricultural Extension Center, 812 Tsukidono, Saito, Miyazaki 881-0023, Japan \\ 6) Present address: Tyubu Agricultural Extension Center, 1401 Iwachino, Kunitomi, Miyazaki 880-1111, Japan \\ 7) Present address: Miyazaki Prefecture Agricultural Academy, 5733 Mochida, Takanabe, Miyazaki 884-0005, Japan
}

A genetic linkage map of the sweet pepper (Capsicum annuum L.) using an intraspecific doubled-haploid (DH) population was primarily constructed by amplified fragment-length polymorphism (AFLP) using the high efficiency genome scanning (HEGS) system and random amplified polymorphic DNA (RAPD). Linkage analysis was done using a total of 518 molecular markers that consisted of 382 AFLP, 122 RAPD, 3 RFLP, 7 SCAR and 4 CAPS markers. The linkage groups consisted of 11 large linkage groups (56.7 to $118.5 \mathrm{cM})$ and 5 small linkage groups $(1.8$ to $33.1 \mathrm{cM})$, covering a total distance of $1043.1 \mathrm{cM}$ with an average distance between 224 framework markers of $4.6 \mathrm{cM}$. AFLP markers could be developed quickly using HEGS, even in an intraspecific DH population in which it is generally difficult to detect polymorphisms in comparison with interspecific crossing populations. The map was constructed essentially in two months. Linkage analysis also provided three AFLP markers and an RAPD marker linked to PMMoV resistance $\left(L^{3}\right)$, and an AFLP marker linked to $C$ that was required for expression of pungency. A closer marker linked to $C$, Plastid-lipidAssociated Protein-simple sequence repeat (PAP-SSR), a microsatellite marker linked to $C$, was found at a distance of $0.6 \mathrm{cM}$. We examined the usefulness of PAP-SSR with three species in Capsicum using fragment analysis and nucleotide sequences, many alleles were found at this locus. The results suggested that these markers could be effective in marker-assisted selection (MAS) programs for sweet pepper breeding purposes.

Key Words: Capsicum, sweet pepper, PMMoV, pungency, high efficiency genome scanning (HEGS), amplified fragment length polymorphism (AFLP), linkage map, doubled-haploid (DH) population.

\section{Introduction}

The genus Capsicum belongs to Solanaceae. This genus contains five species, i.e, C. annuum, C. frutescens, $C$. baccatum, C. pubescens and $C$. chinense. $C$. annuum is known as pepper, sweet pepper or paprika $(C$. annuum $\mathrm{L}$. var. angulosum Miller or var. grossum Bailey), and is cultivated globally for spices, vegetables, colorants and medical supplies. In recent years, DNA markers linked to various agriculturally important characters have been developed in Capsicum species. Using these linkage markers markerassisted selection (MAS) has now become possible in some traits. However, to widen the possibility of MAS in Capsicum breeding, a method for rapid construction of linkage

Communicated by A. Kojima

Received August 30, 2004. Accepted May 17, 2005.

*Corresponding author (e-mail: sugita-tohru@pref.miyazaki.lg.jp) maps should be developed.

Restriction fragment-length polymorphism (RFLP), random amplified polymorphic DNA (RAPD) (Williams et al. 1990), simple sequence repeat (SSR also designated as microsatellites) (Tautz 1989, Weber and May 1989) and amplified fragment-length polymorphism (AFLP) (Vos et al. 1995) are generally used to construct the linkage map. However, detection of RFLP requires a great deal of labor and much more DNA than the other PCR-based methods (e.g. RAPD, SSR and AFLP).

On the contrary, RAPD is simpler than other techniques, its reproducibility is reportedly poor. Although AFLP can detect many bands at once and can be mapped efficiently, labeled primers with radioactive isotope or fluorescent chemicals are needed to detect it. However, the procedure in this technique is complicated. Recently Kawasaki and Murakami (2000) developed a high-efficiency genome scanning (HEGS) system, a modified detection system for 
AFLP. The system uses small electrophoresis units with non-labeled primers, and can also be used for detection of SSR polymorphism. Combining HEGS and RAPD, genetic maps can be easily constructed with high cost performance.

In Capsicum, Tanksley et al. (1988), Prince et al. (1993), Lefebvre et al. (1995) and Livingstone et al. (1999) have constructed genetic maps using RFLP with tomato probes. Kang et al. (2001) constructed a genetic map using 150 RFLP markers and 430 AFLP markers on an interspecific $\mathrm{F}_{2}$ population. Furthermore, DNA markers linked to various useful characteristics have been identified. These markers include disease resistance to pepper mild mottle virus (PMMoV; $L^{4}$ ) (Matsunaga et al. 2003), cucumber mosaic virus (Ben et al. 2001a), tomato spotted wilt virus (Moury et al. 2000) and potato virus Y (Caranta et al. 1999), fruit shape (Ben et al. 2001b), pungency (Blum et al. 2002) and mature fruit color (Popovsky and Paran 2000, Huh et al. 2001). Moreover, we have developed SCAR markers linked to $\mathrm{PMMoV}$ resistance $\left(L^{3}\right)$ (Sugita et al. 2004).

We then tried to construct the linkage map using AFLP/ HEGS, RAPD for comparison with AFLP/HEGS and RFLP based on an intraspecific DH population derived from a crossing between 'K9-11' and 'AC2258'. Furthermore, we mapped the $L^{3}$ and the $C$ locus required for expression of pungency and verified the possibility of securing many DNA markers linked to each loci.

\section{Materials and Methods}

\section{Plant materials and DNA extraction}

A DH population $(\mathrm{n}=176)$ was obtained by anther culture of an $\mathrm{F}_{1}$ hybrid between 'K9-11' (C. annuum L.) and 'AC2258' (C. annuum L.). 'K9-11' harbors the $L^{3}$ gene derived from PI159236, and is a bell-like sweet pepper (Yanokuchi et al. 1993, Sugita et al. 2004). It is susceptible to phytophthora blight and has no pungency, and its immature fruit color is dark green. 'AC2258' is resistant to phytophthora blight and is pungent. The color of the immature fruit of this line is light yellow. Anther culture was performed using the method described by Dumas de Vaulx et al. (1981) with a minor modification (Todoroki et al. 1994, Yamaguchi et al. 1994).

Genomic DNA was extracted from young leaf tissues using the CTAB method as described by Murray and Thompson (1980), and Nucleon PHYTOPURE (Amersham LIFE SCIENCE, Buckinghamshire).

\section{RAPD analysis}

DNA samples were screened with a total of 2,397 combinations of two arbitrary 10 and 12 mer primers (Operon Technologies, Calif; BEX, Tokyo). The amplification conditions were adopted for RAPD analysis with minor modifications. The PCR reaction mixture consisted of $20 \mathrm{ng}$ of template DNA, $1 \times$ reaction buffer $(10 \mathrm{mM}$ Tris $\mathrm{HCl}, \mathrm{pH} 8.3,1.5$ $\mathrm{mM} \mathrm{MgCl} 2,50 \mathrm{mM} \mathrm{KCl}$ ) (Takara Biomedicals, Otsu), 200 $\mu \mathrm{M}$ of dNTPs, $0.2 \mu \mathrm{M}$ of random primers and two units of
rTaq DNA polymerase (Takara Biomedicals, Otsu) in a total reaction volume of $20 \mu \mathrm{l}$. DNA amplification was performed in a Perkin-Elmer GeneAmp PCR System 9700 and 9600. The mixture was initially denatured at $95^{\circ} \mathrm{C}$ for $2 \mathrm{~min}$, followed by 45 cycles of PCR amplification with denaturation at $94^{\circ} \mathrm{C}$ for $1 \mathrm{~min}$, primer annealing at $35^{\circ} \mathrm{C}$ for $2 \mathrm{~min}$, primer extension at $72^{\circ} \mathrm{C}$ for $3 \mathrm{~min}$, and finally incubated at $72^{\circ} \mathrm{C}$ for $7 \mathrm{~min}$. The PCR products were separated by electrophoresis on a $2 \%$ agarose gel (SeaKem GTG agarose, FMC BioProducts, Rockland) with $0.5 \times$ TBE buffer $(44.5 \mathrm{mM}$ Tris-borate, $1 \mathrm{mM}$ EDTA), and stained with ethidium bromide.

\section{AFLP analysis}

The amplification conditions were adopted for AFLP analysis and initially described by Vos et al. (1995). The electrophoresis conditions and the band-detections were adopted for HEGS as described by Kawasaki and Murakami (2000) and Kawasaki et al. (2003). Genomic DNA of $250 \mathrm{ng}$ digested with MseI 5 unit/EcoRI 5 unit, MseI 5 unit/PstI 5 unit or MseI 5 unit/XbaI 5 unit. Digested fragments were ligated to each adaptor of restriction enzyme combination. The first amplification was performed using pre-amplification primers (Table 1). The first PCR products diluted with $1 / 10$ TE (1 mM Tris hydroxymethyl aminomethane, $0.1 \mathrm{mM}$ disodium dihydrogen ethylenediamine tetraacetate dehydrate, $\mathrm{pH}$ 8.0) buffer to $1 / 100$ were used as template DNA for second amplification. The second amplification was performed using selective primers (Table 1 ) in a $10 \mu$ l total reaction

Table 1. Nucleotide sequences of the primers and adapters used in AFLP analysis

\begin{tabular}{|c|c|}
\hline Primers/Adapters & Nucleotide sequences \\
\hline MseI adapter 1 & $5^{\prime}$-gac gat gag tcc tga g-3' \\
\hline MseI adapter 2 & $5^{\prime}$-tac tca gga ctc at- $3^{\prime}$ \\
\hline EcoRI adapter 1 & $5^{\prime}$-ctc gta gac tgc gta cc- $3^{\prime}$ \\
\hline EcoRI adapter 2 & $5^{\prime}$-aat tgg tac gca gtc tac- $3^{\prime}$ \\
\hline PstI adapter 1 & $5^{\prime}$-ctc gta gac tgc gta cat gca-3' \\
\hline PstI adapter 2 & $5^{\prime}$-tgt acg cag tct ac- $3^{\prime}$ \\
\hline XbaI adapter 1 & $5^{\prime}$-ctc gta gac tgc gta cc- $3^{\prime}$ \\
\hline XbaI adapter 2 & $5^{\prime}$-cta ggg tac gca gtc tac-3' \\
\hline MseI primer $(+1)$ & $5^{\prime}$-gat gtg tcc tga gta ac-3' \\
\hline EcoRI primer $(+1)$ & $5^{\prime}$-gac tgc gta cca att ca-3' \\
\hline PstI primer $(+1)$ & $5^{\prime}$-gac tgc gta cat gca gg-3' \\
\hline XbaI primer $(+1)$ & $5^{\prime}$-gac tgc gta ccc tag ac- $3^{\prime}$ \\
\hline MseI primer $(+3)$ & $\begin{array}{l}5^{\prime} \text {-gat gtg tcc tga gta ac+aa(M1), ac(M2), } \\
\text { ag(M3), at(M4), ca(M5), cc(M6), } \operatorname{cg}(\mathrm{M} 7), \\
\text { ct(M8), ga(M9), gc(M10), gg(M11), gt(M12), } \\
\text { ta(M13), tc(M14), } \operatorname{tg}(\mathrm{M} 15), \operatorname{tt}(\mathrm{M} 16)-3^{\prime}\end{array}$ \\
\hline EcoRI primer $(+3)$ & $\begin{array}{l}5^{\prime} \text {-gac tgc gta cca att ca + aa(E1), ac(E2), } \\
\text { ag(E3), at(E4), ca(E5), cc(E6), cg(E7), ct(E8), } \\
\text { ga(E9), gc(E10), gg(E11), gt(E12), ta(E13), } \\
\text { tc(E14), tg(E15), tt(E16)-3' }\end{array}$ \\
\hline PstI primer $(+3)$ & $5^{\prime}$-gac tgc gta cat gca gg + ga, gt, ta, tc, tg, tt- $3^{\prime}$ \\
\hline XbaI primer $(+3)$ & $\begin{array}{l}5^{\prime} \text {-gac tgc gta ccc tag ac }+\operatorname{cc}(X 6), \operatorname{cg}(X 7) \\
\operatorname{ct}(X 8), \operatorname{ga}(X 9), \operatorname{gc}(X 10), \operatorname{gg}(X 11)-3^{\prime}\end{array}$ \\
\hline
\end{tabular}


Table 2. Nucleotide sequences and information of the primers used in this study

\begin{tabular}{|c|c|c|c|c|c|}
\hline Markers ${ }^{1)}$ & Primers & Description & Forward primer & Reverse primer & Reference \\
\hline CAPS & $\mathrm{CCS}$ & C. annuum capsanthin/capsorubin synthase gene & $5^{\prime}$-gggtacatggtggctcgtag-3' & $5^{\prime}$-gagggacaagagtggagcag-3' & X77289 \\
\hline CAPS & Sn-2 & C. annuum $S n-2$ gene & $5^{\prime}$-tgaagtgtggaggaagcetg-3' & $5^{\prime}$-gcgtcgattgatggggccaa-3' & X79231 \\
\hline CAPS & LCYB & C. annuum lycopene Beta-cyclase & $5^{\prime}$-gcaccttgttgggaaaatatggatacgc- $3^{\prime}$ & $5^{\prime}$-gatcccagataagtcgaattcattc-3' & X86221 \\
\hline CAPS & N4F6R6 & Nicotiana glutinosa virus resistance $(\mathrm{N})$ gene & $5^{\prime}$-aggctctgggataagggaactacca- $4^{\prime}$ & $5^{\prime}$-tgatggtggaaccaactcgggatc- $3^{\prime}$ & U15605 \\
\hline SSR & PAP-SSR & C. annuum fibrillin gene; C.annuum PAP gene & $5^{\prime}$-ctccaaactacccctggatttttc- $3^{\prime}$ & 5'-gtcaatccaaatagacttttaaatgtgc-3' & X77290, AJ131456 \\
\hline SCAR & ASC002 & CAPS marker linked to $P v r 4$ in pepper ${ }^{2)}$ & $5^{\prime}$-cgaagagagaaggtc- $3^{\prime}$ & $5^{\prime}$-tcagggtaggttatt-3' & Caranta et al. 1999 \\
\hline SCAR & H6-4 & SCAR marker linked to $B s 3$ in pepper & $5^{\prime}$-aagcttaacacatctttc-3' & $5^{\prime}$-ttaaacggtggctgttac- $3^{\prime}$ & Pierre et al. 2000 \\
\hline SCAR & H17-52 & SCAR marker linked to $B s 3$ in pepper & $5^{\prime}$-cttatataataacagaggcg-3' & $5^{\prime}$-gtaatgagccacactaac- $3^{\prime}$ & Pierre et al. 2000 \\
\hline SCAR & S19 & CAPS marker linked to $B s 2$ in pepper2) & $5^{\prime}$-ctgaccagccaaacatgg- $3^{\prime}$ & $5^{\prime}$-ctgaccagecetttcaacttac- $3^{\prime}$ & Tai et al. 1999 \\
\hline SCAR & PMFR11 & SCAR marker linked to $L^{3}$ in pepper & $5^{\prime}$-ctgcagaacaacaatggcacg- $3^{\prime}$ & $5^{\prime}$-ggactgcagaggaggaagc- $3^{\prime}$ & Sugita et al. 2004 \\
\hline SCAR & PMFR21 & SCAR marker linked to $L^{3}$ in pepper & $5^{\prime}$-gccaaaatggtaattgaaac-3' & $5^{\prime}$-ggactgcagaggaggaagc- $3^{\prime}$ & Sugita et al. 2004 \\
\hline
\end{tabular}

volume. The second PCR products were separated on $13 \%$ polyacrylamide gels under conditions of $250 \mathrm{~V}$ for $30 \mathrm{~min}$ and $420 \mathrm{~V}$ for $3 \mathrm{hrs}$ in a small vertical electrophoresis unit of $26 \times 26 \mathrm{~cm}$ (Nippon-eido, Tokyo). The gels were stained with SYBR Green I (BMA, Rockland) for $30 \mathrm{~min}$, and were detected with a fluorescent image analyzer (FLA-3000G; Fuji Film, Tokyo).

\section{RFLP, SCAR and CAPS analysis}

Genomic DNA for RFLP analysis extracted by the CTAB method was digested with a restriction enzyme, XbaI, and separated by $0.8 \%$ agarose gel electrophoresis. The gels were transferred onto positively charged nylon membranes (Hybond N+, Amersham-Biosciences, Piscataway) by the capillary transfer method, and baked at $80^{\circ} \mathrm{C}$ for $2 \mathrm{hrs}$. Southern blot hybridization was performed with Gene Images Random-Prime Labelling and Detection System (Amersham-Biosciences, Piscataway) using the tomato probe provided by Cornell University. The SCAR markers were from previously published literature or databases (Table 2). The CAPS markers used were designed based on the known gene sequences with previously established databases (Table 2 ).

\section{PMMoV inoculation and evaluation of pungency}

An isolate of PMMoV (P1.2 pathotype), was collected in Miyazaki Prefecture and used in this study. Young leaves were excised and mechanically inoculated with the purified virus $(20 \mathrm{ng} / \mathrm{ml})$ by rubbing with $\# 500$ carborundum powder. The inoculated leaves were kept in a growth chamber under moist conditions at $25^{\circ} \mathrm{C}$ for $24 \mathrm{hrs}$ with lighting. Local lesions grew on the leaves harboring the $L^{3}$ gene after three to six days. The pungency was evaluated by the organoleptic method, in which placenta tissue of the fruits was tasted 30 to 40 days after bloom.

\section{Design of SSR primers and fragment analysis}

The primers were designed based on the fibrillin gene (Accession No.X77290) that has been renamed the Plastidlipid-Associated Protein (PAP) gene (Accession No. AJ131456 (Pozueta-Romero et al. 1997)) described by Blum et al. (2002). The obtained PCR products were directly sequenced with an ABI310 sequencer (Applied Biosystems, Foster City). The primers labeled with fluorescent chemicals were newly designed from the obtained sequencing data, and the fragment length was analyzed with an ABI310 sequencer and GeneScan ${ }^{\mathrm{TM}}$ (Applied Biosystems, Foster City). The validity of the developed marker was examined with 28 accessions of three species in Capsicum. Furthermore, nucleotide sequences of PAP-SSR fragments on 23 accessions of three species in Capsicum were analyzed with an ABI310 sequencer by direct sequencing.

\section{Data analysis}

Linkage analysis using the DNA markers and two phenotypic loci was performed with the program MAPMAKER Ver. 3.0 (Lander et al. 1987) under the conditions of a maximum recombination fraction of $25 \mathrm{cM}$ and a minimum LOD score above 3.0.

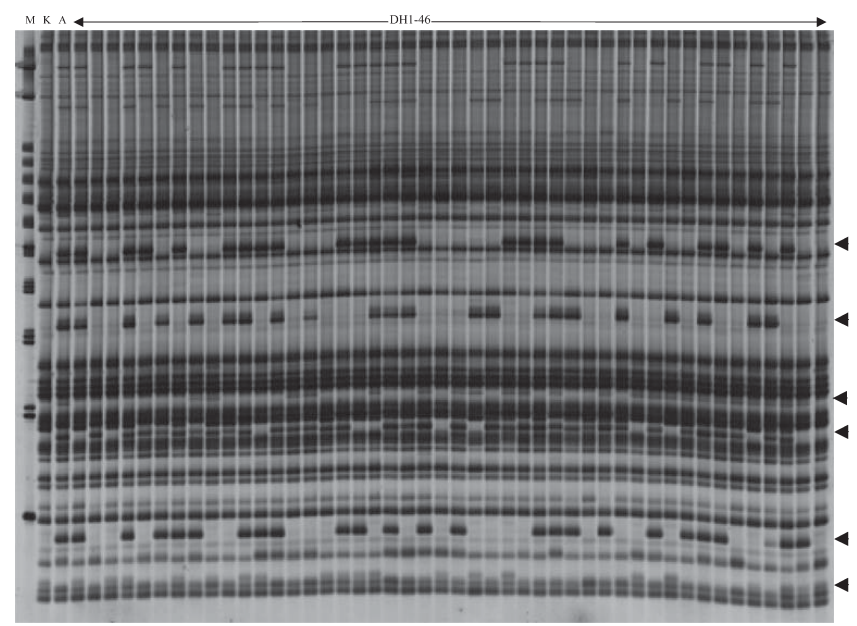

Fig. 1. AFLP analysis of an intraspecific DH population using primer combination M10/E12. M: Molecular marker (100 bp ladder). K: 'K9-11'. A: 'AC2258'. DH1-46: DH individuals. Arrowheads on the right side show polymorphic bands. 


\section{Results and Discussion}

\section{Construction of the linkage map}

Although there was little difference in the polymorphic rate between the RAPD and AFLP analyses as for pepper, the average number of polymorphisms per primer using EcoRI/MseI, PstI/MseI and XbaI/MseI based on AFLP was respectively, 13.6, 8.2 and 12.7 times that based on RAPD. Polymorphisms can be detected more efficiently and quickly than by RAPD (Fig. 1). The average number of polymorphic bands and the average number of bands per primer were greatest for the combination of EcoRI/MseI on AFLP analysis $(E c o \mathrm{RI} / M s e \mathrm{I}>\mathrm{Xba \textrm {I }} / \mathrm{Mse} \mathrm{I}>P s t \mathrm{I} / \mathrm{Mse} \mathrm{I})$, and the polymorphic rate was high for $\mathrm{XbaI} / \mathrm{MseI}$. Having many polymorphisms per primer combination facilitates construction of the map in other crossing populations. When the combination of $E c o R \mathrm{R} / M s e \mathrm{I}$ was used, the bands were more crowded

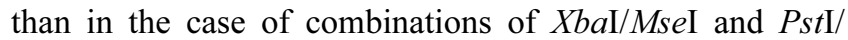
MseI, and difficult to be identified. Kang et al. (2001) have also reported that the combination of EcoRI/MseI generated many AFLP markers than combinations of PstI/MseI, and the large number of polymorphic bands were difficult to score owing to the dense and sometimes overlapping banding patterns.

Linkage analysis was done using a total of 518 molecular markers that consisted of 382 AFLP, 122 RAPD, 3 RFLP, 7 SCAR and 4 CAPS markers. Since many markers were located at the same loci, 224 clear and good quality markers were used as the framework markers. The total of 16 linkage groups (LGs) consisting of 11 large LGs (56.7 to $118.5 \mathrm{cM}$ ) and five small LGs (1.8 to $33.1 \mathrm{cM})$, covering a total distance of $1043.1 \mathrm{cM}$ with an average distance between 224 framework markers of $4.6 \mathrm{cM}$ was obtained (Fig. 2). In addition, 42 out of 382 (11\%) AFLP markers on this map were codominant. However, many AFLP and RAPD markers were located in the limited regions of LG 1 to LG10, LG12 and LG16, and these regions were presumed to be close to the centromere. Markers were gathered in limited regions on other maps of Capsicum (Livingston et al. 1999, Kang et al. 2001). On the contrary, this phenomenon
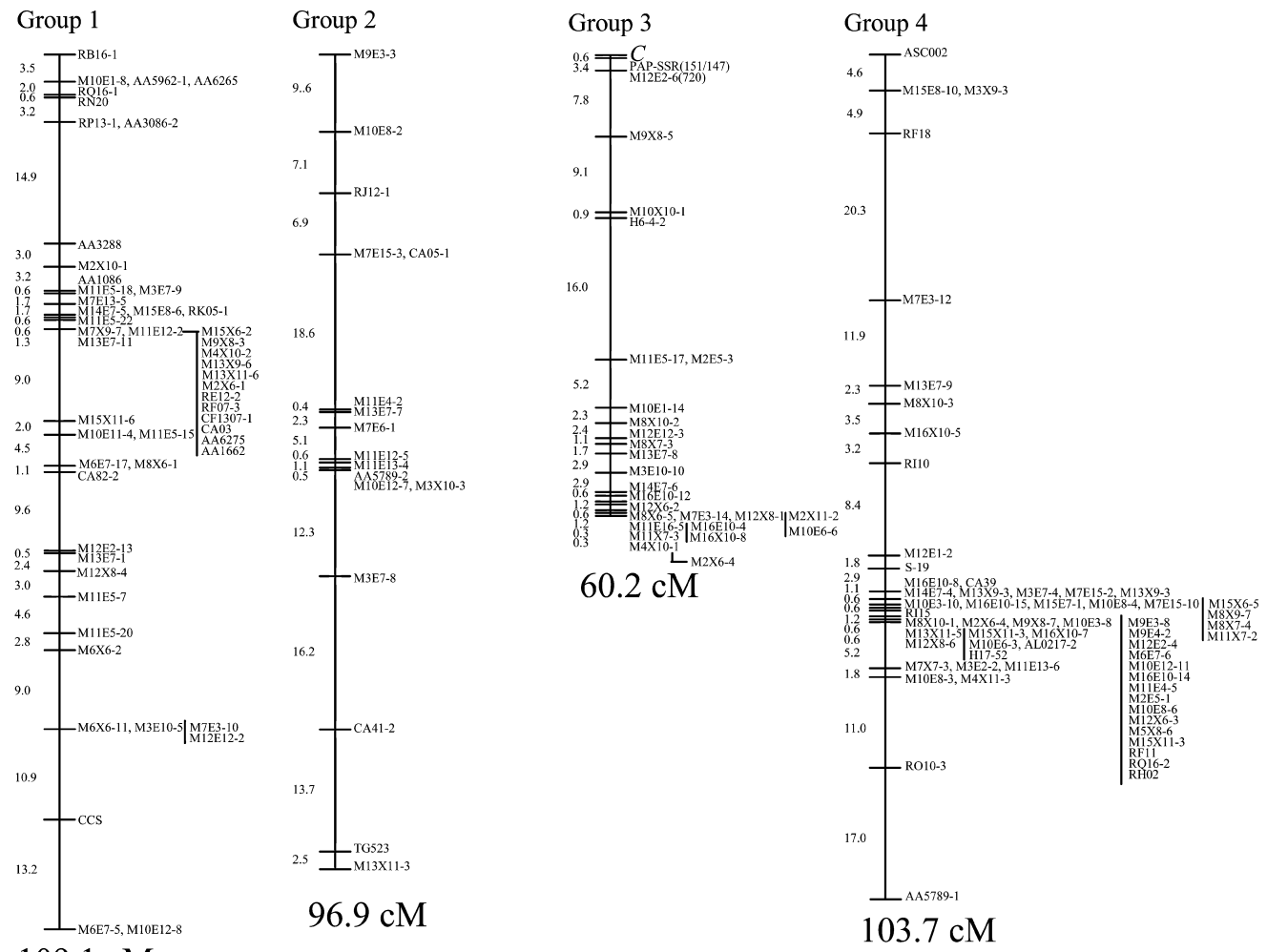

$109.1 \mathrm{cM}$

Fig. 2. A linkage map of the pepper on an intraspecific DH population, derived from $\mathrm{F}_{1}$ crossed between 'K911' (Capsicum annuит L.) and 'AC2258' (C. апnиит L.), using a total of 518 molecular markers consisting of 382 AFLP markers, 122 RAPD markers, three RFLP markers, seven SCAR markers and four CAPS markers. The map is constructed with 227 loci distributed into 16 linkage groups with a total genetic distance of $1040.5 \mathrm{cM}$. CA, CB, RA-Q and AA $(\mathrm{CA} \times \mathrm{CA})$ are RAPD markers on the right side of each linkage group. TG designates the tomato RFLP markers. AFLP markers are named according to the combinations of selective primers in Table 1 used, followed by the numbers given in descending order of fragment length. $C$ is a phenotypic loci for pungency, and $L^{3}$ is a phenotypic loci for resistance to $\mathrm{P}_{1.2}$ in PMMoV. Map distances are in centiMorgans $(\mathrm{cM})$ calculated by the Kosambi function, indicated on the left side of each linkage group. 


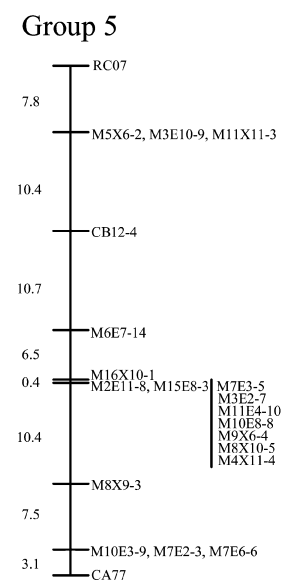

$56.7 \mathrm{cM}$

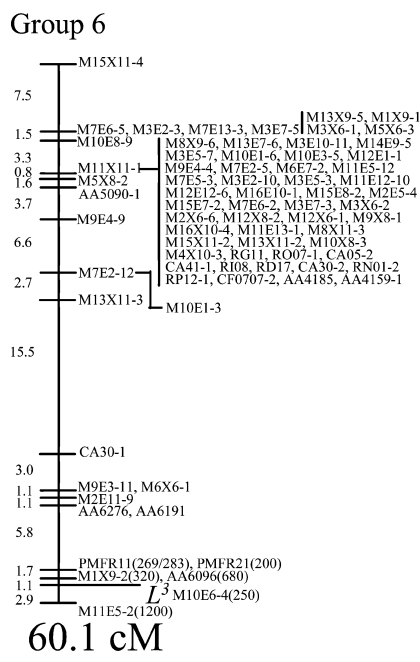

Group 7

${ }^{5.6} T_{\text {TG506 }}^{\mathrm{LCYB}}$

5.9 CA78

8.5

2.4 - $_{2.4873-1}^{\text {CA87 }}$

${ }_{0.4}^{2.4}$ CA $_{0.441, A L 0217-1}^{\text {MaE1 }}$

${ }_{3.4}$ 土一 $^{11.8}$

${ }_{20}^{3.4}=12521-2,210 \times 10.3$

5.3

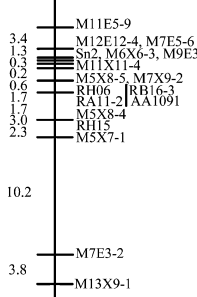

2.6

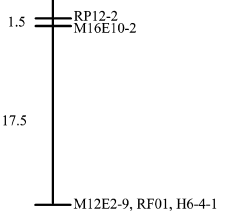

$112.0 \mathrm{cM}$

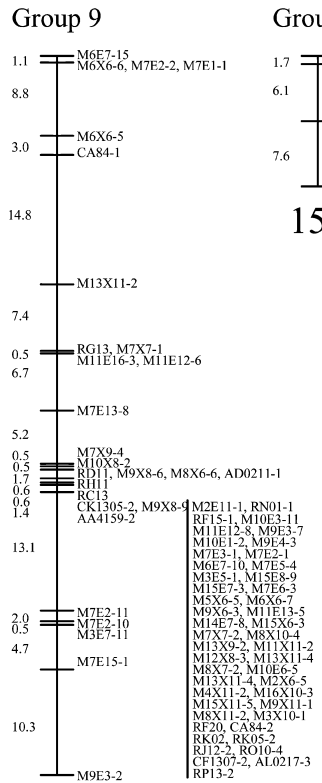

$83.4 \mathrm{cM}$

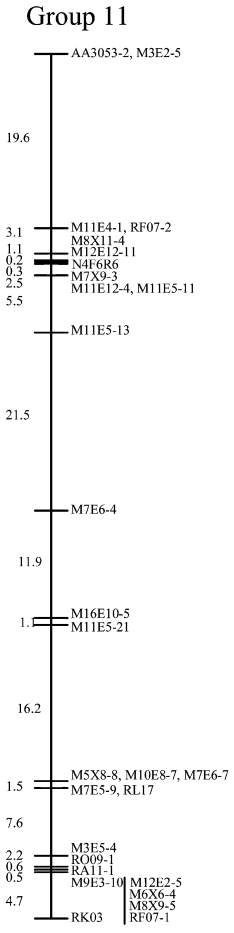

$100.2 \mathrm{cM}$

Fig. 2. (continued)

Group 12

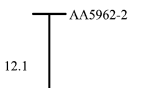

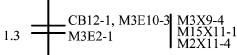

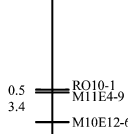

7.5

- ${ }_{\mathrm{M} 6 \mathrm{E} 7 \mathrm{4}}$

7.5

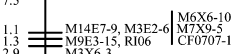

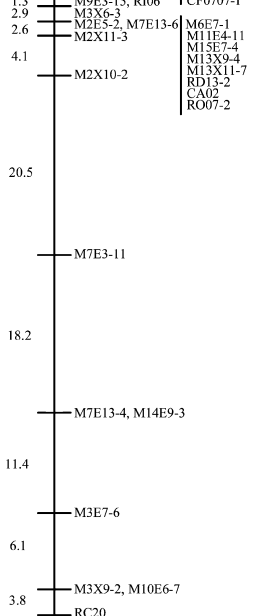

$118.5 \mathrm{cM}$
Group 8

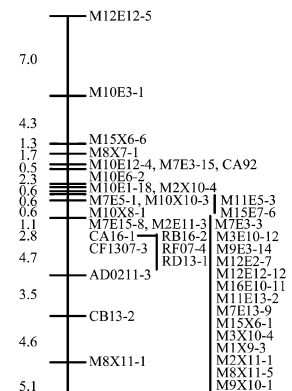

6.9

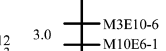

7.

\begin{tabular}{l|l}
7.2 & M11E16-1 \\
&
\end{tabular}

$72.7 \mathrm{cM}$

Group 13

1.8 工 $_{\mathrm{M} 5 \times 8-3}^{\mathrm{MlE5}-16}$

$1.8 \mathrm{cM}$

Group 14

2.7 干

13.7

$\perp_{\text {M12E12-1 }}$

$16.3 \mathrm{cM}$

Group 15

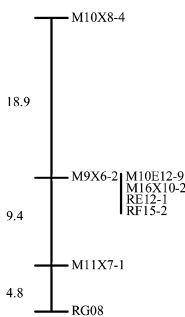

$33.1 \mathrm{cM}$

Group 16

${ }^{2.9}{干_{\mathrm{M} 4 \times 10-5}^{\mathrm{RG} 5}}^{\mathrm{N}}$ 
was not so marked in other crops (Hordeum vulgare (Hori et al. 2003) and Oryza sativa (Kawasaki et al. 2003). It is considered to be the genome characteristic of this genus since it is recognized on other linkage maps of Capsicum (Livingston et al. 1999, Kang et al. 2001). In addition, there were 52 markers for which the distortion of the segregation ratio exceeded $\mathrm{P}<0.01$, and these regions were located mainly on LG3, LG9 and LG11. AFLP markers could be developed quickly and easily using HEGS, even in an intraspecific DH population in which it is generally difficult to detect polymorphisms in comparison with interspecific crossing populations. The map was constructed essentially in two months.

Moreover, by linkage analysis using the constructed linkage map and the result of PMMoV inoculation on a $\mathrm{DH}$ population, we could map the $L^{3}$ locus on the end of LG6 (Fig. 2). Since $L^{3}$ is reported to be located on the end of the 11 th chromosome (Livingstone et al. 1999, Lefebvre et al. 2002), it is considered that LG6 on our map corresponds to the 11th chromosome. By linkage analysis using the constructed linkage map, we could map the $C$ locus for pungency trait at the end of LG3 (Fig. 2). Since $C$ is located on the middle of the second chromosome (Ben et al. 2001b), LG3 on our map is considered to correspond to the second chromosome.

\section{Development of the DNA markers linked to $L^{3}$}

An AFLP marker M10E6-4 (250 bp) cosegregated with the $L^{3}$ locus, an AFLP marker M1X9-2 (320 bp) and a RAPD marker AA6096 (680 bp) located on $1.1 \mathrm{cM}$ from $L^{3}$, and an AFLP marker M11E5-2 (1.2 kbp) at the opposite side of 2.9 cM across $L^{3}$, were found (Fig. 2 and Table 3). Boukema (1982) reported that four pathotypes, $\mathrm{P}_{0}, \mathrm{P}_{1}, \mathrm{P}_{1.2}$ and $\mathrm{P}_{1.2 .3}$, could be identified in PMMoV, while four types of allelic resistance genes, $L^{1}, L^{2}, L^{3}$ and $L^{4}$, were found in Capsicum species. It was also reported that a clear gene-for-gene response was observed. As a result, the $L^{3}$ gene derived from PI159236 (C. chinense) is assumed to confer resistance to $\mathrm{P}_{0}, \mathrm{P}_{1}$ and $\mathrm{P}_{1.2}$, and the $L^{4}$ gene derived from PI260429 (C. chacoense) is assumed to confer resistance to $\mathrm{P}_{0}, \mathrm{P}_{1}, \mathrm{P}_{1.2}$ and $\mathrm{P}_{1.2 .3}$, while many other accessions carrying only $L^{l}$ or $L^{2}$ genes are not resistant to $\mathrm{P}_{1.2}$ and $\mathrm{P}_{1.2 .3}$. Fig. 3 shows the position of the $L$ resistance to $\mathrm{PMMoV}$ and linked markers in Capsicum. An RFLP marker TG36 using a tomato probe, was mapped at $4.0 \mathrm{cM}$ from $L^{3}$ with an interspecific $\mathrm{DH}$ population by Lefebvre et al. (1995). The SCAR markers, PMFR $11_{269}$, PMFR $11_{283}$ and PMFR2 $1_{200}$ were mapped at $4.0 \mathrm{cM}$ from $L^{3}$ with an intraspecific $\mathrm{DH}$ population by Sugita et al. (2004) using a bulked segregant analysis method. A SCAR marker, WA31-1500S, was mapped at $1.5 \mathrm{cM}$ from $L^{4}$ with an intraspecific $\mathrm{F}_{2}$ population by Matsunaga et al. (2003). It is an $L^{4}$-specific dominant marker, and is detected only in the accessions harboring the $L^{4}$ gene. In this study, three AFLP markers and an RAPD marker linked to $L^{3}$ were obtained at the locus closer than what is already reported. These closely linked molecular markers on both sides of the resistance gene, $L^{3}$, enable us to select desirable geno-

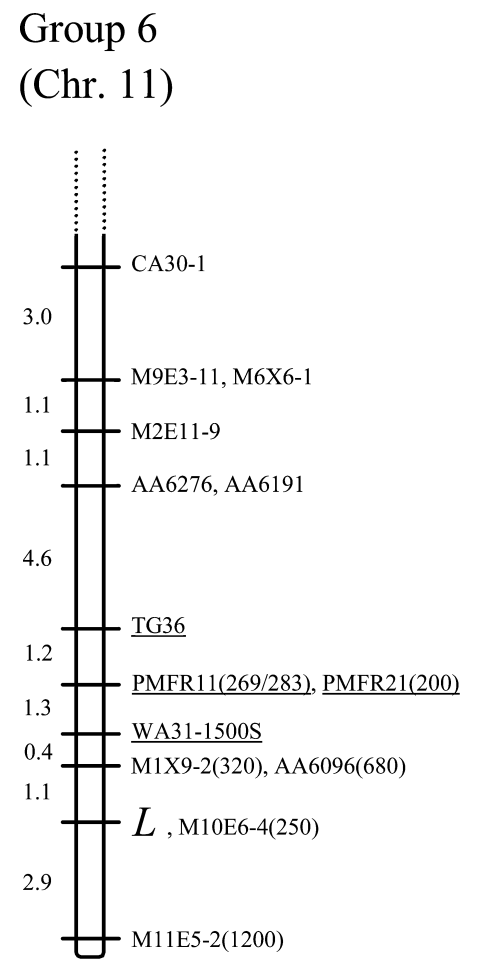

Fig. 3. Position of the $L$ locus for resistance to PMMoV and linked markers in Capsicum. Underlined markers, TG36 using a tomato probe, was mapped by Lefebvre et al. (1995). WA311500S, a SCAR marker was mapped by Matsunaga et al. (2003). PMFR $11_{269}$, PMFR $11_{283}$ and PMFR2 $1_{200}$, the SCAR markers were mapped by Sugita et al. (2004). Map distances are in centiMorgans $(\mathrm{cM})$ calculated by the Kosambi function, indicated on the left side of the linkage map.

Table 3. Frequency distribution of PMMoV resistance dependent on markers in $\mathrm{DH}^{1)}$ populations

\begin{tabular}{lrrrrr}
\hline \hline \multirow{2}{*}{ DNA markers } & \multicolumn{2}{c}{ resistant } & & \multicolumn{2}{c}{ susceptible } \\
\cline { 2 - 3 } \cline { 5 - 6 } & $+^{2}$ & - & & + & - \\
\hline PMFR21 $_{200}{ }^{3}$ & 88 & 10 & & 3 & 72 \\
PMFR1 $_{269}$ & 88 & 0 & & 4 & 0 \\
PMFR11 & 3 & 0 & & 68 & 0 \\
AA6096 & 86 & 1 & & 1 & 71 \\
M1X9-2 & 98 & 1 & & 1 & 71 \\
M10E6-4 & 97 & 0 & & 0 & 75 \\
M11E5-2 & 92 & 5 & & 0 & 74 \\
\hline
\end{tabular}

1) One-hundred-and-sixty-three individuals were examined for PMFR $11_{269}$ and PMFR $11_{283}, 159$ for AA6096 680,171 for M1X9-2 320,172 for M10E6-4 250 and 171 for M11E5-2 1200 markers.

2) + and - indicate presence and absence of the DNA marker.

3) PMFR $21_{200}$, PMFR $11_{269}$ and PMFR $11_{283}$ are SCAR markers described by Sugita et al. (2004).

types in a segregation population even if the virus resistance gene is linked to an undesirable trait. Furthermore, conversion of these markers to specific primer-based markers makes MAS easier. 
Development of the DNA markers linked to the pungency trait

An AFLP marker, M12E2-6 (720 bp) was closely linked to $C$ at a distance of $4.0 \mathrm{cM}$. A CAPS marker was mapped at $0.4 \mathrm{cM}$ from $C$ with an interspecific $\mathrm{F}_{2}$ population between $C$. annuum and $C$. frutescens by Blum et al. (2002), and this CAPS marker was developed using the clone obtained from the subtracted library of cDNA. The sequence was just the same as the reported sequence of the fibrillin gene (No. X77290) in the database (Blum et al. 2002). In the present study, we also attempted to map the fibrillin gene using the sequence in the database in order to secure DNA markers closer to the $C$. However, no polymorphism was found in this region between the parents. Comparing the sequencing data in the region of the fibrillin gene (renamed PAP gene) revealed the polymorphism in the microsatellite region, located $900 \mathrm{bp}$ upstream from the start codon of the gene. The pungent parent, 'AC2258' had 25 repeats of TA, while non-pungent, 'K9-11' had 23 repeats at this microsatellite. Then this microsatellite was named PAP-SSR.

When linkage analysis was performed with PAP-SSR using the primers labeled with fluorescent chemicals and the $C$ locus obtained from evaluating pungency, the PAP-SSR was located at the distance of $0.6 \mathrm{cM}$ from $C$. The usefulness of PAP-SSR was examined with 28 accessions of three species in Capsicum. Most of the accessions were homozygous, but some of them were heterozygous in this microsatellite. As many as nine alleles were found within C. annuum. In addition, additional allele was found in $C$. chinense (Table 4).

Nucleotide sequences of PAP-SSR fragments were analyzed on 23 accessions of three species in Capsicum (Fig. 4). 'Jalapeño' had 36 repeats of TA at this microsatellite locus, 'Kyousuzu' had 27, 'K9-11', 'Miogi', 'Shousuke', 'California Wonder', 'Spirit', 'Special', 'Fiesta', 'Suizan', 'Leila' and 'Berumasari' had 25, 'AC2258' had 23, 'Criollo de Morelos 334', 'Fushimiamanaga', 'Takanotsume' and 'Kyounami' had eleven, LS2341 and PI260429 had ten, 'Habanero', 'Miemidori' and 'Shishitou' had eight, and PI159236 had five repeats. Furthermore, 'Miemidori', 'Shishitou', 'Habanero' and PI159236 had, respectively, four bp insertions of TTTT, TTTT, TGTT and ATTT with the exception of the microsatellite. 'Miemidori' and 'Shishitou' had seven bp deletions of AATAATT. PI159236 and PI260429 had a point transition of G from T or T from A. Many alleles were found in this microsatellite region. Since some useful traits, such as disease resistance, are often found in various pungent wild species, the SSR marker obtained in the present study will be very useful in pepper breeding.

Table 4. Genotypes of PAP-SSR loci in 28 accessions of three species in Capsicum, using the primers labeled with fluorescent chemicals

\begin{tabular}{|c|c|c|c|c|}
\hline Accessions & Species & $\begin{array}{l}\text { Country } \\
\text { of origin }\end{array}$ & Pungency & $\begin{array}{c}\text { Genotype of } \\
\text { SSR loci }\end{array}$ \\
\hline K9-11 & Capsicum annuиm & Japan & non-pungent & $151 / 151$ \\
\hline $\mathrm{AC} 2258$ & C. annuиm & Mexico & pungent & $147 / 147$ \\
\hline $\mathrm{F}_{1}(\mathrm{~K} 9-11 \times \mathrm{AC} 2258)$ & C. аппиит & Japan & pungent & $147 / 151$ \\
\hline Kyouyutaka & C. anпuиm & Japan & non-pungent & $149 / 155$ \\
\hline Kyousuzu & C. anпuиm & Japan & non-pungent & $155 / 155$ \\
\hline Tosahikari-D & C. апnиum & Japan & non-pungent & $121 / 151$ \\
\hline Shousuke & C. апnиuт & Japan & non-pungent & $151 / 151$ \\
\hline Miogi & C. апnиит & Japan & non-pungent & $151 / 151$ \\
\hline Himukamidori & C. anпuиm & Japan & non-pungent & $121 / 151$ \\
\hline Kyounami & C. annuum & Japan & non-pungent & $122 / 122$ \\
\hline Berumasari & C. annuum & Japan & non-pungent & $151 / 151$ \\
\hline Miemidori & C. annuиm & Japan & non-pungent & $115 / 115$ \\
\hline Takanotsume & C. anпuиm & Japan & pungent & $121 / 121$ \\
\hline Fushimiamanaga & C. аппиит & Japan & non-pungent & $121 / 121$ \\
\hline Nanzenji & C. аппиит & Japan & pungent & $121 / 151$ \\
\hline Shishitou & C. аппиит & Japan & pungent & $115 / 115$ \\
\hline Wonder bell & C. аппиит & Japan & non-pungent & $151 / 151$ \\
\hline California Wonder & C. аппиит & USA & non-pungent & $151 / 151$ \\
\hline Leila & C. апnиuт & EU & non-pungent & $151 / 151$ \\
\hline Special & C. апnиит & EU & non-pungent & $151 / 151$ \\
\hline Spirit & C. аппиит & EU & non-pungent & $151 / 151$ \\
\hline Suizan & C. апnиит & $\mathrm{EU}$ & non-pungent & $151 / 151$ \\
\hline Habanero & C. chinense & Mexico & pungent & $120 / 120$ \\
\hline Criollo de Morelos 334 & C. апnиит & Mexico & pungent & $121 / 121$ \\
\hline Jalapeño & C. апnиит & Guatemala & pungent & $176 / 176$ \\
\hline LS 2341 & C. аппиит & Malaysia & pungent & $120 / 120$ \\
\hline PI 159236 & C. chinense & Peru & pungent & $116 / 116$ \\
\hline PI 260429 & C. chacoense & Argentina & pungent & $120 / 120$ \\
\hline
\end{tabular}




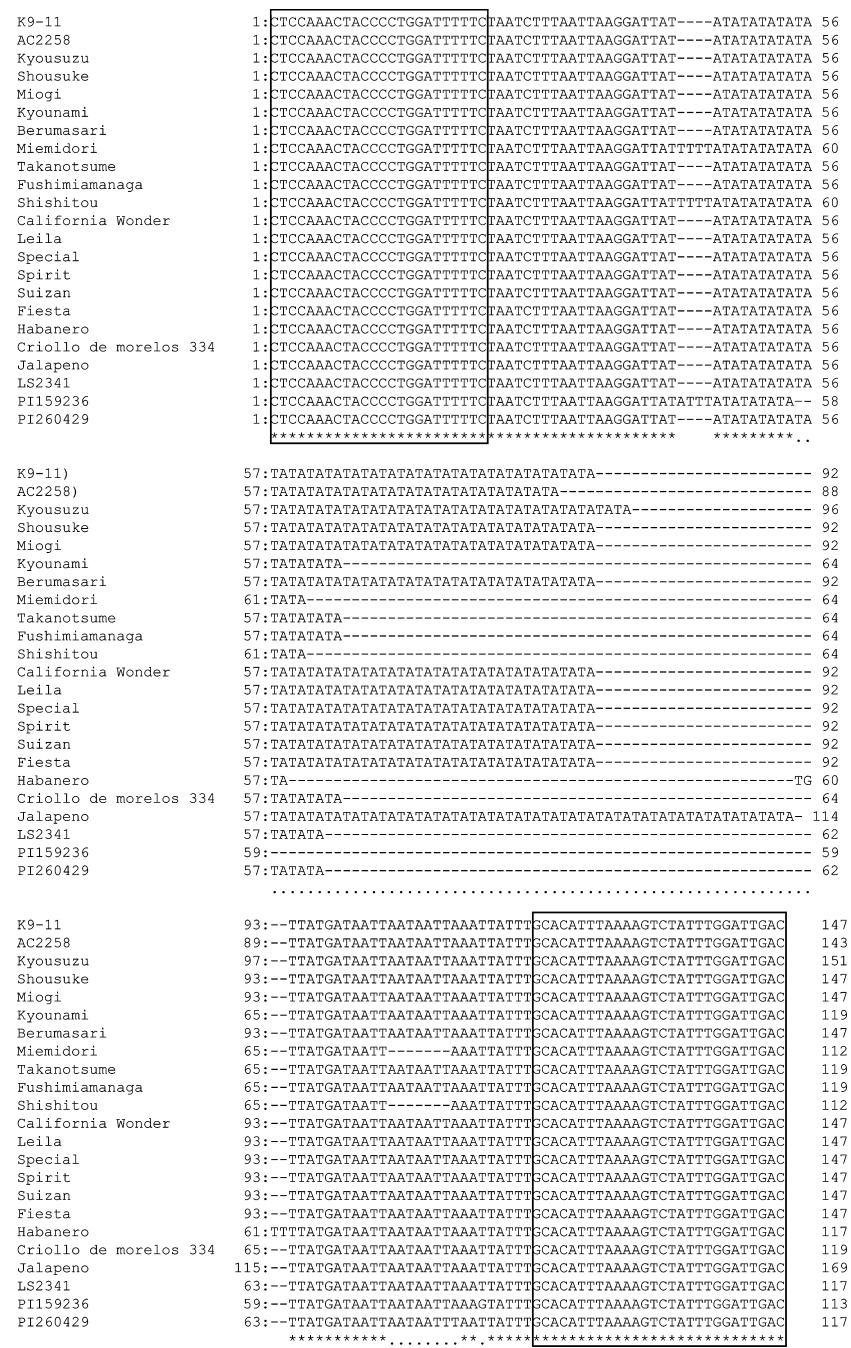

Fig. 4. Nucleotide sequences of PAP-SSR fragments on 23 accessions of three species in Capsicum. The microsatellite region located $900 \mathrm{bp}$ upstream from the start codon of the fibrillin gene (Accession No.X77290). Black borders indicate the positions of SSR primers used in this study. Hyphen indicates area with lacking parts. Asterisk indicates area with coincidental parts.

In this study, we rapidly constructed a linkage map covering a total distance of $1043.1 \mathrm{cM}$ with 224 framework markers using HEGS/AFLP and RAPD, and phenotypic traits. Although the use of HEGS/AFLP required more skill than that of RAPD, HEGS/AFLP enabled us to construct the linkage map inexpensively and quickly. Compared with conventional AFLP technology, HEGS/AFLP made possible efficient construction of a genetic map without using a radioactive isotope or special facilities. We obtained markers linked to $L^{3}$, and a microsatellite marker for the pungency locus, $C$.

Further studies will focus on 1) converting DNA markers linked to $L^{3}$ into SCAR markers, and 2) developing DNA markers linked to resistance for phytophthora blight and immature fruit colors.

\section{Acknowledgments}

We are grateful to Dr. M. Hirai, Kyoto Prefectural University for suggestions, encouragement and critical review of the manuscript. This work was supported by a grant from Miyazaki Prefecture, Japan.

\section{Literature Cited}

Ben,C.A., R.Grube, M.Lapidot and M.Jahn (2001a) Identification of quantitative trait loci associated with resistance to cucumber mosaic virus in Capsicum annuum. Theor. Appl. Genet. 102: $1213-1220$

Ben,C.A., I.Paran, R.Grube, M.Jahn, R.Wijk and J.Peleman (2001b) QTL mapping of fruit-related traits in pepper (Capsicum annuum). Theor. Appl. Genet. 102: 1016-1028.

Blum,E., K.Liu, M.Mazourek, E.Y.Yoo, M.Jahn and I.Paran (2002) Molecular mapping of the $C$ locus for presence of pungency in Capsicum. Genome 45: 702-705.

Boukema,I.W. (1982) Resistance to TMV in Capsicum chacoense Hunz. is governed by an allele of the $L$-locus. Capsicum Newsl. 3: $47-48$.

Caranta,C., A.Thabuis and A.Palloix (1999) Development of a CAPS marker for the Pvr4 locus: A tool for pyramiding potyvirus resistance gene in pepper. Genome 42: 1111-1116.

Dumasde Vaulx,R., D.Chambonnet and E.Pochard (1981) In vitro culture of pepper (Capsicum annuum L.) anthers: high rate plant production from different genotypes by $+35^{\circ} \mathrm{C}$ treatments. Agronomie. 1: 859-864.

Hori,K., T.Kobayashi, A.Shimizu, K.Sato, K.Takeda and S.Kawasaki (2003) Efficient construction of high-density linkage map and its application to QTL analysis in barley. Theor. Appl. Genet. 107: 806-813.

Huh,J.H., B.C.Kang, S.H.Nahm, S.Kim, K.S.Ha, M.H.Lee and B.D. Kim (2001) A candidate gene approach identified phytoene synthase as the locus for mature fruit color in red pepper (Capsicum spp.). Theor. Appl. Genet. 102: 524-530.

Kang,B.C., S.H.Nahm, J.H.Huh, H.S.Yoo, J.W.Yu, M.H.Lee and B.D.Kim (2001) An interspecific (Capsicum annuum $\times C$. chinense) $F_{2}$ linkage map in pepper using RFLP and AFLP markers. Theor. Appl. Genet. 102: 531-539.

Kawasaki, S. and Y.Murakami (2000) Genome Analysis of Lotus japonicus. J. Plant Res. 113: 497-506.

Kawasaki, S., Y.Murakami, H. Imaizumi-Anraku, A.Shimizu and I.Mikami (2003) Construction of High-Density Map, Genome Library, and Saturation Mapping of Nodulation Genes. In "Biotechnology in Agriculture and Forestry, vol. 52, Brassicas and Legumes", Nagata, T. and S. Tabata (eds.), Springer, Berlin, p. 183-202.

Lander,E., P.Green, J.Abrahamson, A.Barlow, M.Daley, S.Lincoln and L.Newburg (1987) MAPMAKER: An interactive computer package for constructing primary genetic linkage maps of experimental and natural populations. Genomics 1: 174-181.

Lefebvre, V., A.Palloix, C.Caranta and E.Pochard (1995) Construction of an intraspecific integrated linkage map of pepper using molecular markers and doubled-haploid progenies. Genome 38: $112-121$.

Lefebvre, V., S. Pflieger, A. Thabuis, C.Caranta, A. Blattes, J.C. Chauvet, A.M.Daubèze and A.Palloix (2002) Towards the saturation of the pepper linkage map by alignment of three 
intraspecific maps including known-function genes. Genome 45: 839-854.

Livingstone,K.D., V.K.Lackney, J.R.Blauth, W.R.Van and M.K.Jahn (1999) Genome mapping in Capsicum and the evolution of genome structure in the Solanaceae. Genetics 152: 1183-1202.

Matsunaga,H., T.Saito, M.Hirai, T.Nunome and T.Yoshida (2003) DNA markers linked to Pepper Mild Mottle Virus (PMMoV) resistant locus $\left(L^{4}\right)$ in Capsicum. J. Japan. Soc. Hort. Sci. 72: 218-220.

Moury,B., S.Pflieger, A.Blattes, V.Lefebvre and A.Palloix (2000) A CAPS marker to assist selection of tomato spotted wilt virus (TSWV) resistance in pepper. Genome 43: 137-142.

Murray,M. and W.F.Thompson (1980) Rapid isolation of high molecular weight plant DNA. Nucleic Acids Res. 8: 4321-4325.

Prince, J.P., E.Pochard and S.D.Tanksley (1993) Construction of a molecular linkage map of pepper and a comparison of synteny with tomato. Genome 36: 404-417.

Popovsky, S. and I.Paran (2000) Molecular genetics of the $y$ locus in pepper: its relation to capsanthin-capsorubin synthase and to fruit color. Theor. Appl. Genet. 101: 86-89.

Pozueta-Romero, J., F. Rafia, G. Houlne, C.Cheniclet, J.P.Carde, M.L.Schantz and R.Schantz (1997) A ubiquitous plant housekeeping gene, PAP, encodes a major protein component of bell pepper chromoplasts. Plant Physiol. 115: 1185-1194.

Sugita,T., K.Yamaguchi, Y.Sugimura, R.Nagata, K.Yuji, T.Kinoshita and A.Todoroki (2004) Development of SCAR markers linked to $L^{3}$ gene in Capsicum. Breed. Sci. 54: 111-115.

Tanksley,S.D., R.Bernatzky, N.Lapitan and J.P.Prince (1988) Conser- vation of gene repertoire but not gene order in pepper and tomato. Proc. Natl. Acad. Sci. 85: 6419-6423.

Tautz,D. (1989) Hypervariability of simple sequences as a general source for polymorphic DNA markers. Nucleic Acids Res. 17: 6463-6471.

Todoroki, A., T.Kashino, R.Nagata, K.Yamaguchi and Y.Hatanaka (1994) Doubled-haploid plant obtained by sweet pepper anther culture. Kyusyu Agr. Res. 56: 180 (in Japanese).

Vos, P., R. Hogers, M. Bleeker, M. Reijans, T. Lee, M. Hornes, A.Frijters, J.Pot, J.Peleman, M.Kuiper and M.Zabeau (1995) AFLP: a new technique for DNA fingerprinting. Nucleic Acids Res. 23: 4407-4414.

Weber,J.L. and P.E.May (1989) Abundant class of human DNA polymorphisms which can be typed using the polymerase chain reaction. Am. J. Hum. Genet. 44: 388-396.

Williams, J.G.K., A.R.Kubelik, K.J.Livak, J.A.Rafalski and S.V. Tingey (1990) DNA polymorphisms amplified by arbitrary primers are useful as genomic markers. Nucleic Acids Res. 18: 6531-6535.

Yamaguchi,K., T.Kashino, R.Nagata, Y.Hatanaka and T.Todoroki (1994) Identification of ploidy by character of stomata in anther culture of sweet pepper. Kyusyu Agr. Res. 56: 181 (in Japanese).

Yanokuchi,Y., H.Baba, M.Fujimori, T.Kobayashi, K.Ito, S.Motoki, K.Okamoto, T.Oguchi and M.Kobayashi (1993) New sweet pepper variety 'Bellmasari'. Bull. Nagano Chushin Agr. Exp. Sta. 11: 21-35 (in Japanese with English summary). 